\title{
Maternal thyroid hormone status in pre-eclampsia: a tertiary care hospital based study
}

\author{
Sonali Deshpande ${ }^{1}$, Kanan Yelikar ${ }^{1}$, Shreyas Patil $^{1}$, Smita Andurkar $^{2}$
}

\author{
${ }^{1}$ Department of Obstetrics \& Gynaecology, GMC, Aurangabad, Maharashtra, India \\ ${ }^{2}$ Department of Preventive \& Social Medicine, GMC, Aurangabad, Maharashtra, India
}

Received: 25 September 2015

Accepted: 29 October 2015

\section{*Correspondence:}

Dr. Sonali Deshpande,

E-mail: sonalisd97@yahoo.co.in

Copyright: $\odot$ the author(s), publisher and licensee Medip Academy. This is an open-access article distributed under the terms of the Creative Commons Attribution Non-Commercial License, which permits unrestricted non-commercial use, distribution, and reproduction in any medium, provided the original work is properly cited.

\begin{abstract}
Background: The objective of the study was to study the association between thyroid hormone status with preeclampsia and correlate it with severity of pre-eclampsia.

Methods: In this case control study, 200 women attending tertiary care hospital between the study period September 2012 to August 2014 were recruited in the study in which 100 women were cases (diagnosed as preeclampsia) and 100 were taken as control (healthy normotensive women). Assessment of thyroid status of cases and control was done. Association was studied between thyroid hormone status and pre-eclampsia and co-related with severity of preeclampsia.

Results: There was a significant association between pre-eclampsia and thyroid hypofunction (overt and sub clinical hypothyroidism) with P-value being 0.0406. Odds-ratio indicates that preeclampsia group have chance of higher TSH $(>4.8 \mathrm{mIU} / \mathrm{L})$ by 2.19 times. (95\% confidence intervals $=1.0223-4.6934)$. The association between severity of preeclampsia and thyroid hypofunction (subclinical and overt hypothyroidism) was found to be statistically significant $(\mathrm{p}=0.02717)$. Odds ratio indicates that severe preeclampsia group have 2.87 times more chance of thyroid hypofunction.

Conclusions: In the present study a positive association was found between thyroid hypofunction and pre-eclampsia and it was found to be statistically significant. With regards to the results of the present study, "the measurement of serum levels of FT3, FT4 and TSH" can be suggested as a criterion for prediction of pre-eclampsia.
\end{abstract}

Keywords: Pre-eclampsia, Thyroid Hormone status, TSH

\section{INTRODUCTION}

Thyroid dysfunction constitutes one of the commonest endocrine disorders during pregnancy after diabetes mellitus. ${ }^{1} \quad$ Pregnancy is associated with profound modifications in the regulation of thyroid function. These changes are the result of the various factors like an increase of thyroid-binding globulin (TBG) due to elevated estrogens and human chorionic gonadotropin (HCG), increased renal losses of iodine due to increased glomerular filtration rate, modifications in the peripheral metabolism of maternal thyroid hormones, and modifications in iodine transfer of placenta. It has long been recognized that maternal thyroid hormone excess or deficiency can influence maternal outcomes like miscarriages, anaemia in pregnancy, preeclampsia, abruption placenta and postpartum hemorrhage and fetal outcome at all stages of pregnancy like prematurity, low birth weight, increased neonatal respiratory distress and fetal thyroid abnormalities which may justify screening for thyroid functions in pregnancy. In India incidence of pre-eclampsia as recorded from hospital statistics vary 
widely from $5-15 \% .^{2}$ This disorder is unique to human pregnancy in which numerous genetic immunological and environmental factors interact. Therefore, it is a leading cause of maternal and fetal morbidity and mortality throughout the world and still is one of the most complex problems in obstetrics. Although, pregnancy is usually associated with very mild hyperthyroxinemia which is the presence of a free thyroxin (FT4) value above the 2.5th percentile with a thyrotropin (TSH) level within the reference range. ${ }^{3}$ Women complicated with preeclampsia have high incidence of hypothyroidism that might correlate with the severity of preeclampsia. The mechanism of hypothyroidism in pre-eclamptic women is not well identified but changes in thyroid function are due to high circulation of estrogens. Excess placental soluble fms-like tyrosine kinase 1 (sFlt1) may contribute to endothelial dysfunction, hypertension, and proteinuria in preeclampsia. ${ }^{4}$ There are limited number of studies on thyroid function in preeclampsia and it has been suggested that there may be an existence of mutual influences between preeclampsia and thyroid function. Therefore, this study has been undertaken to evaluate the association between thyroid hormone status and preeclampsia and co-relate it with the severity of preeclampsia.

\section{METHODS}

\section{Study design}

It was a case control study.

\section{Setting}

The study was carried out in tertiary care hospital.

\section{Study population}

200 women were recruited in the study in which 100 women were cases and 100 were taken as controls.

\section{Inclusion criteria}

Diagnosed cases of preeclampsia.

\section{Exclusion criteria}

H/o heart diseases, pregnancy induced hypertension without proteinuria, $\mathrm{H} / \mathrm{o}$ pre-eclampsia already on antihypertensive drugs, H/o thyroid disease, H/o any metabolic disorder before or during pregnancy, H/o intake of any medication that might affect thyroid function like drugs, e.g. glucocorticoids, Phenobarbitone, Ferrous sulphate, $\mathrm{H} / \mathrm{o}$ any renal disease, Medical disorders like RHD, Epilepsy, H/o Molar pregnancy, H/o Multiple pregnancy, H/o congenitally malformed fetus.

\section{Study period}

The study was carried out between September 2012 to August 2014.

\section{Case}

Case was defined on the basis of inclusion and exclusion criteria i.e. diagnosed cases of pre-eclampsia characterized by elevation of blood pressure of more than $140 \mathrm{mmHg}$ systolic or more than $90 \mathrm{~mm}$ of $\mathrm{Hg}$ diastolic with proteinuria (more than $300 \mathrm{mg} / \mathrm{l}$ in 24 hours specimen) after 20 weeks of gestation in previously normotensive non proteinuric pregnant women.

\section{Control}

The control constituted of equal number of matched age, parity, socio-demographic status, gestational age; healthy normotensive pregnant women visiting the labour ward.

This study was approved by Institutional Ethical Committee. Written informed consent was obtained from all participants recruited in study after they had been made aware of purpose of study. Particulars of the women were noted such as name, age, symptoms, menstrual history for menarche, last menstrual period and past menstrual cycles, history of present pregnancy. Past obstetric history was asked for duration of marriage, infertility, gravidity and parity status, recurrent abortions, pre-eclampsia, growth restriction, low birth weight, preterm delivery, prematurity, late pregnancy losses, neonatal deaths, and mental retardation in previous pregnancy. Past medical history was asked for any associated medical disorders like diabetes, thyroid disorders, exposure to radiation or autoimmune disorders. Significant surgical history, family history was also asked. A thorough clinical examination including height, weight, pulse, blood pressure, pedal oedema, thyroid enlargement, etc. was done followed by systemic examination. In obstetrical examination gestational age, presentation and amount of liquor was noted and fetal heart sounds were auscultated with stethoscope.

All preliminary and baseline investigations like complete blood count, blood grouping and typing, urine routine and microscopy and blood sugar were done. Ultrasonography was done for fetal growth, liquor and placenta. All investigations pertaining to complications of preeclampsia like liver and kidney function tests, serum uric acid were also done. Assessment of thyroid status of cases and controls were done with serum Free T3, T4 and TSH for which $10 \mathrm{ml}$ venous blood sample was taken from the cubital vein irrespective of NBM status. (i) In cases, after the diagnosis of pre-eclampsia was made but before the initiation of the antihypertensive treatment and before the delivery and (ii) In controls, after admission. All samples were sent to the laboratory where Sera were separated and stored at -200c until assayed. Free T3, free 
T4 and TSH were measured using fully automated chemiluminescence system (CLIA kits). Further, depending upon the fT4 and fT3 values, all women were classified as follows.

Table 1: Classification according FT3, FT4 and TSH levels.

\begin{tabular}{|llll|}
\hline Functions & TSH & Free T3 & Free T4 \\
\hline $\begin{array}{l}\text { Overt } \\
\text { hypothyroidism }\end{array}$ & Elevated & Low & Low \\
\hline $\begin{array}{l}\text { Subclinical } \\
\text { hypothyroidism }\end{array}$ & Elevated & Normal & Normal \\
\hline Euthyroid & Normal & Normal & Normal \\
\hline $\begin{array}{l}\text { Subclinical } \\
\text { hyperthyroidism }\end{array}$ & Low & Normal & Normal \\
\hline $\begin{array}{l}\text { Overt } \\
\text { hyperthyroidism }\end{array}$ & Low & Elevated & Elevated \\
\hline
\end{tabular}

Table 2: Recommended trimester specific TSH levels.

\begin{tabular}{|llll|}
\hline Trimester & FT3 & FT4 & TSH \\
First & $1.91-3.5$ & $0.86-1.77$ & 0.1 to 2.5 \\
Trimester & $\mathrm{pg} / \mathrm{ml}$ & $\mathrm{pg} / \mathrm{ml}$ & $\mu \mathrm{IU} / \mathrm{ml}$ \\
\hline Second & $2.8-4.2$ & $0.63-1.29$ & 0.2 to 3.0 \\
Trimester & $\mathrm{pg} / \mathrm{ml}$ & $\mathrm{pg} / \mathrm{ml}$ & $\mu \mathrm{IU} / \mathrm{ml}$ \\
\hline Third & $2.4-4.1$ & $0.66-1.12$ & 0.3 to 3.0 \\
Trimester & $\mathrm{pg} / \mathrm{ml}$ & $\mathrm{pg} / \mathrm{ml}$ & $\mu \mathrm{IU} / \mathrm{ml}$ \\
\hline
\end{tabular}

Women were also classified according to the severity of pre-eclampsia into severe and non-severe. ${ }^{5}$

Association was noted between thyroid hormone status and pre-eclampsia and co-related with severity with oddsratio.

\section{Statistical analysis}

Statistical comparison between cases and controls was done using chi-square test, student $t$ test which ever was appropriate, $\mathrm{p}$ value below 0.05 was considered to be statistically significant. Strength of association between thyroid hormone status and pre-eclampsia was studied by calculating odds-ratio.
Table 3 shows the distribution of cases and controls according to age, parity and gestational age. The two groups were comparable in age, parity, sociodemographic and clinical characteristics. Table 4 shows the distribution according to mean levels of thyroid hormone. The difference in Mean TSH level and Mean FT3 levels in cases and controls was found be statistically significant $(\mathrm{p}<0.001)$.

\section{RESULTS}

Table 3: Distribution of cases and controls according to age, parity and gestational age.

\begin{tabular}{|c|c|c|c|c|c|}
\hline Mean & Cases & $\begin{array}{l}\text { Contr } \\
\text { ols }\end{array}$ & $\begin{array}{l}\mathrm{t} \\
\text { value }\end{array}$ & $\begin{array}{l}\mathrm{p} \\
\text { value }\end{array}$ & df \\
\hline $\begin{array}{l}\text { Age in } \\
\text { years }\end{array}$ & $\begin{array}{l}23.08 \pm \\
0.301\end{array}$ & $\begin{array}{l}22.78 \\
\pm \\
0.281\end{array}$ & 0.729 & $\begin{array}{l}P= \\
0.467\end{array}$ & 198 \\
\hline Parity & $\begin{array}{l}0.68 \pm \\
0.1162\end{array}$ & $\begin{array}{l}0.86 \pm \underline{ \pm} \\
0.1318\end{array}$ & 1.024 & $\begin{array}{l}P= \\
0.212\end{array}$ & 198 \\
\hline $\begin{array}{l}\text { Gestational } \\
\text { age in } \\
\text { weeks }\end{array}$ & $\begin{array}{l}36.99 \pm \\
0.2665\end{array}$ & $\begin{array}{l}38.07 \pm \\
0.2285\end{array}$ & 3.088 & $\begin{array}{l}\mathrm{P}= \\
0.128\end{array}$ & 198 \\
\hline
\end{tabular}

Table 4: Distribution according to mean levels of thyroid hormone.

\begin{tabular}{|cccccc|}
\hline Mean & Cases & $\begin{array}{c}\text { Contro } \\
\text { ls }\end{array}$ & $\begin{array}{c}\mathrm{t} \\
\text { value }\end{array}$ & $\mathrm{p}$ value & df \\
Mean & & & & & \\
TSH & $3.14 \pm$ & $1.92 \pm$ & 5.370 & $\mathrm{P}<$ & 198 \\
$(\mu \mathrm{IU} / \mathrm{ml}$ & 0.1895 & 0.124 & & 0.001 & \\
\hline Mean & & & & & \\
FT3 & $3.077 \pm$ & $3.49 \pm$ & 6.298 & $\mathrm{P}<$ & 198 \\
Level & 0.0464 & 0.046 & & 0.001 & 198 \\
$(\mathrm{pg} / \mathrm{ml})$ & & & & & \\
\hline $\begin{array}{c}\text { Mean } \\
\text { FT4 }\end{array}$ & $0.897 \pm$ & $0.86 \pm$ & 1.197 & $\mathrm{P}=0.23$ & 198 \\
Level & 0.0159 & 0.014 & & 26 & \\
$(\mathrm{pg} / \mathrm{ml})$ & & & & & \\
\hline
\end{tabular}

Table 5: Distribution of cases and controls according to thyroid status.

\begin{tabular}{|c|c|c|c|c|c|c|c|}
\hline \multirow{2}{*}{ Thyroid Status } & \multicolumn{2}{|l|}{ Cases } & \multicolumn{2}{|l|}{ Controls } & \multicolumn{2}{|l|}{ Total } & Test of Significance \\
\hline & $(n=100)$ & $\%$ & $(n=100)$ & $\%$ & $(n=200)$ & $\%$ & \multirow{5}{*}{$\begin{array}{l}\chi^{2}=4.19 \\
\mathrm{P}=0.0406 \\
\mathrm{OR}=2.19 \\
95 \% \mathrm{CI}(1.0223-4.6934)\end{array}$} \\
\hline Euthyroid & 77 & 77 & 88 & 88 & 165 & 82.5 & \\
\hline Sub* Clinically Hypothyroid & 20 & 20 & 10 & 10 & 30 & 15 & \\
\hline Overt* Hypothyroid & 3 & 3 & 2 & 2 & 5 & 2.5 & \\
\hline Total & 100 & 100 & 100 & 100 & 200 & 100 & \\
\hline
\end{tabular}

* Both were clubbed calculate odds-ratio and its statistical significance. 95\%CI -Confidence Interval 95\%. 
Table 6: Correlation of thyroid status with severity of pre-eclampsia.

\begin{tabular}{|c|c|c|c|c|c|c|c|}
\hline \multirow{3}{*}{ Thyroid status } & \multicolumn{4}{|l|}{ Cases } & \multirow{2}{*}{\multicolumn{2}{|c|}{ Total }} & \multirow{2}{*}{$\begin{array}{l}\text { Test of } \\
\text { Significance }\end{array}$} \\
\hline & \multicolumn{2}{|c|}{ Severe Pre-eclampsia } & \multicolumn{2}{|c|}{ Non Severe Pre-eclampsia } & & & \\
\hline & $(n=37)$ & $\%$ & $(\mathrm{n}=63)$ & $\%$ & $(n=100)$ & $\%$ & \multirow{5}{*}{$\begin{array}{l}\chi^{2}=4.88 \\
P=0.02717 \\
O R=2.87 \\
95 \% \text { CI } \\
(1.10-7-46)\end{array}$} \\
\hline Euthyroid & 24 & 64.86 & 53 & 84.13 & 77 & 77.00 & \\
\hline Subclinical* hypothyroid & 11 & 29.73 & 9 & 14.29 & 20 & 20.00 & \\
\hline Overt* Hypothyroid & 2 & 5.41 & 1 & 1.59 & 3 & 3.00 & \\
\hline Total & 37 & 100 & 63 & 100 & 100 & 100 & \\
\hline
\end{tabular}

*Both were clubbed together to calculate odds-ratio with confidence interval 95\%

In Table 5, this difference in Mean FT4 levels in cases and controls was not found to be statistically significant $(\mathrm{P}=0.2326)$.

There was a significant association between preeclampsia and thyroid hypofunction (overt and sub clinical hypothyroidism) with P-value being 0.0406.Odds-ratio indicates that preeclampsia group have chance of higher TSH (>4.8 mIU/L) by 2.19 times. $(95 \%$ confidence intervals $=1.0223-4.6934)$.

Table 6 shows the correlation of Thyroid hormone status with severity of Pre-eclampsia. The association between severity of pre-eclampsia and thyroid hypofunction (subclinical and overt hypothyroidism) was found to be statistically significant $(\mathrm{p}=0.02717)$. Odds ratio indicates that severe preeclampsia group have 2.87 times more chance of thyroid hypofunction.

\section{DISCUSSION}

Pre-eclampsia is a serious complication of pregnancy with unknown etiology that may occur at any stage of second or third trimester. Different studies are controversial regarding thyroid hormone levels in preeclampsia. This study was undertaken to contribute to the on-going controversy.

In this study, we studied the thyroid hormone status in pre-eclampsia and tried to correlate it with the severity.

In Present study, the difference in Mean TSH level in cases and control was found to be statistically significant. In a study by Dhananjaya BS et al also reported TSH levels were elevated in pre-eclamptic women as compared to normal pregnant women, which could indicate the possible etiology for pre-eclampsia. ${ }^{6}$ Elevated levels could be used as predictor of preeclampsia.

Qublan et al in their study observed no significant difference in the levels of FT4, FT3 and TSH between normal and Pre-eclampsia groups at various gestational age and concluded that thyroid function is not altered in pre-eclampsia, therefore does not reflect the severity of pre-eclampsia. ${ }^{7}$ Nayereh Khadem et al reported no significant difference in the levels of T3, T4 and TSH between pre-eclampsia and normal pregnancy. ${ }^{8}$ This difference in the results of present study could be due to various geographical areas, different races and different diets.

Nahid Mostaghel et al reported no significant difference in cases and controls in thyroid levels. ${ }^{9}$ This may be due to the fact that the blood sample was taken just at the time of diagnosis of pre-eclampsia. It is possible that low titers of T3 and T4 along with high TSH titers would be observed at a later stage of pre-eclampsia with severe disease and low plasma albumin levels. In present study, When thyroid status was correlated with severity of preeclampsia there was significant association $(\mathrm{P}=0.02717)$ with odds-ratio 2.87 (95\% confidence intervals $=1.1046-$ 7.4611) between severity of pre-eclampsia and thyroid hypofunction (subclinical and overt hypothyroid).

\section{CONCLUSION}

To conclude, in the present study a positive association was found between thyroid hypofunction and preeclampsia and it was found to be statistically significant.

The findings of this study support the hypothesis that changes in $\mathrm{FT}_{3}, \mathrm{FT}_{4}$ and $\mathrm{TSH}$ levels could be a possible etiology of pre-eclampsia.

However, the association between thyroid function and pre-eclampsia needs further investigation because of the small number of subjects.

This study recommends that a multicentric study with large population is needed to support the hypothesis that thyroid hormone abnormalities are associated with preeclampsia. However with regards to the results of the present study, "the measurement of serum levels of $\mathrm{FT}_{3}$, $\mathrm{FT}_{4}$ and TSH" can be suggested as a criterion for prediction of pre-eclampsia. 
Funding: No funding sources

Conflict of interest: None declared

Ethical approval: The study was approved by the Institutional Ethics Committee

\section{REFERENCES}

1. Negro R, Farmoso G, Mangieri T. Levothyroxine treatment in euthyroid pregnant women with autoimmune thyroid disease: effects on obstetrical complications. J Clin Endocrinol Metab. 2006;91:2587-91.

2. Dutta DC. Hypertensive disorders in pregnancy. In Text book of Obstetrics including perinatology and contraception. 6th edition, Calcutta: New central book agency. 2004:221-42.

3. Borst GC, Eil C, Burman KD. Euthyroid hyperthyroxinemia. Ann Intern Med. Mar 1983;98(3):366-78.

4. Stagnaro-Green A, Abalovich M, Alexander E, Azizi F, Mestman J, Negro R. Guidelines of the American Thyroid Association for the Diagnosis and Management of Thyroid Disease during Pregnancy and Postpartum. Thyroid. 2011;21(10):1081-125.

5. Gary CF, Leveno KJ, Bloom SC, Hauth JC, Gilstrap L, Wenstrom KD. Pregnancy Hypertension, In
Williams Obstetrics $23^{\text {rd }}$ Edn. New York Meltrawya. 2005:706-714.

6. Dhananjaya BS, Sendil Kumaran D, Venkatesh G, Niranjan M, Shashiraj HK. Thyroid Stimulating Hormone (TSH) levels as a Possible Indicator of Preeclampsia, Journal of Clinical and Diagnostic Research. 2011;5(8):1542-3.

7. Qublan HS, Al Laisi IJ, Hindawi IM, Hiasat MS, Awamleh I, Hamaideh AH, et al. severe preeclampsia and maternal thyroid function. J Obstet Gynecol. 2003;23:244-6.

8. Khadem N, Ayatollahi H, Roodsari FV, Ayati S. Comparison of serum levels of Tri-iodothyroxineT3, Thyroxine T4 and Thyroid- Stimulating Hormone(TSH) in pre-eclampsia and normal pregnancy, Iranian Journal of Reproductive Medicine. 2010;10(1):47-52.

9. Mostaghel N, Tavanayanfar E, Samani EN. Association of Maternal Hypothyroidism with Preeclampsia Iranian Journal of Pathology. 2008;3(2):51-4.

Cite this article as: Deshpande S, Yelikar K, Patil S, Andurkar S. Maternal thyroid hormone status in preeclampsia: a tertiary care hospital based study. Int J Reprod Contracept Obstet Gynecol 2015;4:1853-7. 